Research

\title{
Molecular analysis of hepatitis B virus "a" determinant in asymptomatic and symptomatic Mexican carriers Martha-Eugenia Ruiz-Tachiquín ${ }^{1}$, Hilda-Alicia Valdez-Salazar ${ }^{1}$, Vicencio Juárez-Barreto ${ }^{2}$, Margarita Dehesa-Violante ${ }^{3}$, Javier Torres ${ }^{1}$, Onofre Muñoz-Hernández ${ }^{1}$ and Ma-Teresa Alvarez-Muñoz*1
}

\begin{abstract}
Address: ${ }^{1}$ Unidad de Investigación en Enfermedades Infecciosas, Unidad Médica de Alta Especialidad (UMAE)-Pediatría, Centro Médico NacionalSiglo XXI, Instituto Mexicano del Seguro Social, México DF, México, ${ }^{2}$ Laboratorio de Análisis Clínicos, Unidad Médica de Alta Especialidad (UMAE)-Pediatría, Centro Médico Nacional-Siglo XXI, Instituto Mexicano del Seguro Social, México DF, México and ${ }^{3}$ Clínica de Hepatitis, Departamento de Gastroenterología, Unidad Médica de Alta Especialidad (UMAE)-Hospital General. Centro Médico Nacional-Siglo XXI, Instituto Mexicano del Seguro Social, México DF, México

Email: Martha-Eugenia Ruiz-Tachiquín - mertachiquin@yahoo.com.mx; Hilda-Alicia Valdez-Salazar - hildaavs@yahoo.com.mx; Vicencio JuárezBarreto - vicencio.juarez@imss.gob.mx; Margarita Dehesa-Violante - mdehesa@prodigy.net.mx; Javier Torres - jtorresl57@yahoo.com.mx; Onofre Muñoz-Hernández - onofre.munoz@imss.gob.mx; Ma-Teresa Alvarez-Muñoz* - mtalvarezm@yahoo.com.mx

* Corresponding author
\end{abstract}

Published: II January 2007

Virology Journal 2007, 4:6 doi:10.1 186/1743-422X-4-6

This article is available from: http://www.virologyj.com/content/4/I/6

(C) 2007 Ruiz-Tachiquín et al; licensee BioMed Central Ltd.

This is an Open Access article distributed under the terms of the Creative Commons Attribution License (http://creativecommons.org/licenses/by/2.0), which permits unrestricted use, distribution, and reproduction in any medium, provided the original work is properly cited.
Received: 27 November 2006

Accepted: II January 2007

\begin{abstract}
Background: Hepatitis $B$ virus (HBV) is a small DNA-containing virus with 4 genes, $C, S, X$ and $P$. The $S$ gene codes for the surface antigen $(\mathrm{HBsAg})$, which contains the "a" determinant, the main region for induction of a protective humoral immune response. To compare the genotype and sequence of the "a" determinant between strains isolated from asymptomatic and symptomatic Mexican HBV carriers.

Results: 2 I asymptomatic (blood donors) and 12 symptomatic (with clinical signs and with > I year lamivudine treatment) $\mathrm{HBV}$ carriers were studied; all patients were positive for the $\mathrm{HBs} \mathrm{Ag}$ in serum. Viral load, genotypes, and subtypes were determined in plasma. A fragment of the $S$ gene including the "a" determinant was PCR amplified and sequenced to determine genotype, subtype and to identify mutations. Mean viral load was $0.7965 \times 10^{4}$ copies $/ \mathrm{ml}$ in asymptomatic carriers and $2.73 \times 10^{6}$ copies $/ \mathrm{ml}$ in symptomatic patients. Genotypes $\mathrm{H}, \mathrm{C}$, and $\mathrm{F}$ were identified in asymptomatic individuals; whereas $\mathrm{H}$ was dominant in symptomatic patients. A fragment of $279 \mathrm{bp}$ containing the "a" determinant was amplified from all 33 carriers and sequences aligned with $S$ gene sequences in the GenBank. Mutations identified were YI00N, TI26I, QI29H and NI46K in the asymptomatic group, and $\mathrm{F} 93 \mathrm{I}$ and $\mathrm{AI} 28 \mathrm{~V}$ in the symptomatic group.
\end{abstract}

Conclusion: Differences in genotype and in mutations in the "a" determinant were found between strains from asymptomatic and symptomatic HBV Mexican carriers.

\section{Background}

Hepatitis B virus (HBV) is a small, non-cytopathic virus with a circular partially double-strand DNA genome of approximately $3.2 \mathrm{~Kb}[1]$. The genome has 4 overlapping genes: PreS/S, PreC/C, $X$, and $P$. The Pre $S / S$ gene encodes for the three envelope proteins, large, middle, and small 
or HBsAg. The PreC/C gene encodes for the nucleocapsid protein and HBeAg. The $X$ gene encodes for the transactivating protein $\mathrm{X}$ and the $P$ gene encodes for polymerase with reverse transcriptase (RT) and RNase H activity [1]. The HBsAg contains the major epitopes for induction of a protective humoral immune response [2-6]. These epitopes are localized in the region known as the "a" determinant, between amino acid residues 99 and 169 [710], and are involved in the binding of antibodies against HBsAg. Amino acids changes in this region render mutant strains able to escape immune responses induced by vaccines $[5,6,11,12]$. Immune-escape mutants occur naturally [13-15], and in strains from patients with a weak or negative HBsAg reactivity in detection assays $[10,15]$.

HBV strains are classified into 8 main genomic groups or genotypes, designated A through $\mathrm{H}$ [16-18], arbitrarily defined by an intergroup divergence of more than $8 \%$ based on the complete genomes [16,19-21]. The relationship between subtypes and genotypes has been reported, and several studies have described the geographic distribution for the different HBV subtypes/genotypes $[16,17,20,22-25]$. The study of HBV genotype has recently been focused on the clinical outcome of the infection, since studies suggest a possible association with the natural history and severity of the infection [26].

In Mexico, frequency of HBV chronic carriers is low, and the prevalence of HBsAg in blood donors ranges from 0.15 to $1.4 \%[27,28]$; the frequency of hepatocellular carcinoma is also low [29]. Scarce studies have addressed genetic diversity and amino acids changes in HBsAg of HBV strains from Mexico [30]. The aim of the present work was to study genetic diversity in the $S$ gene of HBV strains from asymptomatic and symptomatic carriers in Mexico. Genotype and mutations in the "a" determinant of the $S$ gene leading to amino acids changes were compared between these two groups.

\section{Results}

We studied 21 asymptomatic HBsAg carriers, 3 women (mean age 30 years old) and 18 men (mean age 42 years old), with average viral load of $0.7965 \times 10^{4}$ copies $/ \mathrm{ml}$; and 12 symptomatic patients, 5 women (mean age 50 years old) and 7 men (mean age 39 years old), with average viral load of $2.7 \times 10^{6} \mathrm{copies} / \mathrm{mL}$ (Table 1$)$. Functional hepatic tests confirmed hepatic damage in symptomatic but not in asymptomatic cases (Table 1). Genotypes were determined by reverse hybridization and sequencing. Genotypes determined by reverse hybridization were $\mathrm{H}$, $\mathrm{C}, \mathrm{F}, \mathrm{C} / \mathrm{H}, \mathrm{C} / \mathrm{F} / \mathrm{H}$ and indeterminate (ID) in asymptomatic cases, whereas in symptomatic patients only $\mathrm{H}$ and $\mathrm{C} / \mathrm{H}$ genotypes were found (Table 2). On the other hand, the genotypes determined with the sequencing technique were only $\mathrm{H}$, and $\mathrm{C}$; genotype $\mathrm{H}$ was the predominant type (Table 2). In four asymptomatic cases the genotype could not be determined (ID) with the reverse hybridization technique, but was identified as genotype $\mathrm{H}$ with the sequencing method. Sequences of the "a" determinant were aligned with sequences of genotypes A-H (Z72478, X98077, АB048704, AB048701, AB032431, AB036907, AF160501, U91827, NC_003977) and analyzed to identify mutations. Mutations identified in HBV strains from the asymptomatic group were Y100N, T126I, Q129H and N146K; whereas in strains from the symptomatic group identified mutations were F93I and A128V. Subtypes found in the asymptomatic group were adw $4 \mathrm{q}+$, adw $1 \mathrm{q}+$, and adrq+; whereas in symptomatic patients subtypes detected where only adw4q+, and adrq+. Altogether, the genotype/subtype most frequent in our population was $\mathrm{H} / \mathrm{adw} 4 \mathrm{q}+$ (Table 2).

Diversity in the amino acid sequence of the "a" determinant among strains from asymptomatic and symptomatic HBV Mexican carriers is presented in Table 3. T113S, S114T, R122K, I126T and P127L were the most frequent in both asymptomatic and symptomatic patients; whereas A159G, R160K, F161Y and V168A were more frequent in symptomatic patients.

\section{Discussion}

In this work we analyzed genetic diversity in HBV isolates from asymptomatic (blood donors) and symptomatic chronic carriers in Mexico. Genotypes were determined with a commercially available reverse-hybridization technique and compared with the sequencing technique. Reverse hybridization allows the detection of infection with mixed genotypes, suggesting that this technique is more reliable than sequencing to detect quasispecies present in lower proportion in the sample; although in some cases it failed to establish the genotype. On the other hand, besides genotyping, nucleic acid sequencing provides information on nucleotide and amino acid sequences of the region investigated, while other molecular methods detect only the point mutations specified by the probes or primers used.

Of interest, a higher diversity in the infecting genotypes was found among asymptomatic carriers $(\mathrm{H}, \mathrm{C}, \mathrm{F}, \mathrm{C} / \mathrm{H}, \mathrm{C} /$ $\mathrm{F} / \mathrm{H}$ ), than in symptomatic patients, where genotype $\mathrm{H}$ was found in all cases and in only one case a $\mathrm{C} / \mathrm{H}$ infection was detected. These results would suggest that in our population, genotype $\mathrm{H}$ strains are more prevalent than $\mathrm{C}$ and $\mathrm{F}$ genotypes in symptomatic cases. This observation is relevant since studies indicate certain association of the genotype with the clinical outcome of the infection; thus, in hepatocellular carcinoma, genotype $\mathrm{C}$ was more prevalent in patients $>50$ years and genotype B more prevalent in patients $<50$ years of age, than in age-matched asymptomatic carriers [37]. Of interest, in our study, genotype C 
Table I: HBV viral load and hepatic function tests of asymptomatic and symptomatic carriers.

\begin{tabular}{lcc}
\hline & Asymptomatic & Symptomatic \\
\hline Test & Average \pm standard deviation & Average \pm standard deviation \\
\hline HBV viral load (copies/mL) & $7,965.57 \pm 8,218.70$ & $2,736,972.86 \pm 4,553,767.67$ \\
Alanine aminotransferase (U/L) & $26.0 \pm 2.12$ & $202.89 \pm 19.80$ \\
Aspartate aminotransferase (U/L) & $24.94 \pm 8.84$ & $104.26 \pm 317.58$ \\
Direct bilirubin $(\mathrm{mg} / \mathrm{dL})$ & $0.14 \pm 0.03$ & $0.26 \pm 0.20$ \\
Total bilirubins $(\mathrm{mg} / \mathrm{dL})$ & $0.53 \pm 0.03$ & $0.91 \pm 0.25$ \\
\hline
\end{tabular}

Table 2: Genotypes and subtypes of the "a" determinant of HBV strains from asymptomatic and symptomatic cases, determined by both reverse hybridization and sequencing techniques.

\begin{tabular}{|c|c|c|c|c|c|c|}
\hline \multirow[b]{3}{*}{ Patient } & \multirow[b]{3}{*}{ Diagnosis } & \multirow[b]{3}{*}{$\begin{array}{l}\text { Viral load (copies/ } \\
\mathrm{ml} \text { ) }\end{array}$} & \multicolumn{4}{|c|}{ Genotyping of "a" determinant } \\
\hline & & & \multicolumn{2}{|c|}{ Reverse hybridization } & \multicolumn{2}{|c|}{ Sequencing } \\
\hline & & & Bands stained & Genotype & Genotype/Subtype & Mutations \\
\hline HBVI & Asymptomatic & 477 & 11,15 & $\mathrm{H}$ & $\mathrm{H} / \mathrm{adw} 4 \mathrm{q}^{+}$ & YIOON \\
\hline $\mathrm{HBV} 2$ & Asymptomatic & 3330 & 11,15 & $\mathrm{H}$ & $\mathrm{H} / \mathrm{adw} 4 \mathrm{q}^{+}$ & \\
\hline HBV3 & Asymptomatic & 7350 & 11,15 & $\mathrm{H}$ & $\mathrm{H} / \mathrm{adw} 4 \mathrm{q}^{+}$ & Q129H \\
\hline HBV5 & Asymptomatic & 32700 & 11,15 & $\mathrm{H}$ & $\mathrm{H} / \mathrm{adw} 4 \mathrm{q}^{+}$ & \\
\hline HBVI9 & Asymptomatic & 43100 & 15 & ID* & $\mathrm{H} / \mathrm{adw} 4 \mathrm{q}^{+}$ & \\
\hline HBV20 & Asymptomatic & 5750 & 11,15 & $\mathrm{H}$ & $\mathrm{H} / \mathrm{adw} 4 \mathrm{q}^{+}$ & \\
\hline HBV22 & Asymptomatic & 10300 & 8,9 & $\mathrm{C}$ & $\mathrm{H} / \mathrm{adw} 4 \mathrm{q}^{+}$ & \\
\hline HBV24 & Asymptomatic & 1010 & 11,15 & $\mathrm{H}$ & $\mathrm{H} / \mathrm{adw} 4 \mathrm{q}^{+}$ & NI46K \\
\hline HBV25 & Asymptomatic & 4500 & $8,9,11,15$ & $\mathrm{C} / \mathrm{H}$ & $\mathrm{H} / \mathrm{adwlq}+$ & TI26I \\
\hline HBV26 & Asymptomatic & 8470 & $8,9,11,14,15$ & $\mathrm{C} / \mathrm{F} / \mathrm{H}$ & $\mathrm{H} / \mathrm{adw} 4 \mathrm{q}^{+}$ & \\
\hline HBV29 & Asymptomatic & 3650 & 11,15 & $\mathrm{H}$ & $\mathrm{H} / \mathrm{adw} 4 \mathrm{q}^{+}$ & \\
\hline HBV30 & Asymptomatic & 869 & 11,15 & $\mathrm{H}$ & $\mathrm{H} / \mathrm{adw} 4 \mathrm{q}^{+}$ & \\
\hline HBV32 & Asymptomatic & 2030 & 11,15 & $\mathrm{H}$ & $\mathrm{H} / \mathrm{adw} 4 \mathrm{q}^{+}$ & \\
\hline HBV35 & Asymptomatic & 215 & 8,9 & C & $\mathrm{Cladrq}^{+}$ & \\
\hline HBV37 & Asymptomatic & 19000 & II & ID & $\mathrm{H} / \mathrm{adw} 4 \mathrm{q}^{+}$ & \\
\hline HBV38 & Asymptomatic & 3920 & 11,15 & $\mathrm{H}$ & $\mathrm{H} / \mathrm{adw} 4 \mathrm{q}^{+}$ & \\
\hline HBV43 & Asymptomatic & 5990 & 14,15 & $\mathrm{~F}$ & $\mathrm{H} / \mathrm{adw} 4 \mathrm{q}^{+}$ & \\
\hline HBV48 & Asymptomatic & 20400 & 11,15 & $\mathrm{H}$ & $\mathrm{H} / \mathrm{adw} 4 \mathrm{q}^{+}$ & \\
\hline HBV49 & Asymptomatic & $<200$ & none & ID & $\mathrm{H} / \mathrm{adrq}^{+}$ & \\
\hline HBV50 & Asymptomatic & 428 & none & ID & $\mathrm{H} / \mathrm{adw} 4 q^{+}$ & \\
\hline HBV62 & Asymptomatic & 12100 & 11,15 & $\mathrm{H}$ & $\mathrm{H} / \mathrm{adw} 4 \mathrm{q}^{+}$ & \\
\hline HBV7 & Chronic hepatitis & 682000 & 11,15 & $\mathrm{H}$ & $\mathrm{H} / \mathrm{adw} 4 \mathrm{q}^{+}$ & \\
\hline HBV9 & Chronic hepatitis & $>200000$ & 11,15 & $\mathrm{H}$ & $\mathrm{H} / \mathrm{adw} 4 \mathrm{q}^{+}$ & \\
\hline HBVIO & Chronic hepatitis & 3970000 & 11,15 & $\mathrm{H}$ & $\mathrm{H} / \mathrm{adw} 4 \mathrm{q}^{+}$ & \\
\hline HBVII & Chronic hepatitis & 8070 & 11,15 & $\mathrm{H}$ & $\mathrm{H} / \mathrm{adw} 4 \mathrm{q}^{+}$ & \\
\hline HBVI2 & Chronic hepatitis & $<200$ & 11,15 & $\mathrm{H}$ & $\mathrm{H} / \mathrm{adw} 4 \mathrm{q}^{+}$ & \\
\hline HBVI3 & Chronic hepatitis & $<200$ & 11,15 & $\mathrm{H}$ & $\mathrm{H} / \mathrm{adw} 4 \mathrm{q}^{+}$ & \\
\hline HBVI4 & Chronic hepatitis & $<200$ & 11,15 & $\mathrm{H}$ & $\mathrm{H} / \mathrm{adw} 4 \mathrm{q}^{+}$ & \\
\hline HBVI5 & Chronic hepatitis & 2560000 & 11,15 & $\mathrm{H}$ & $\mathrm{H} / \mathrm{adw} 4 \mathrm{q}^{+}$ & \\
\hline HBVI6 & Chronic hepatitis & 139000 & 11,15 & $\mathrm{H}$ & $\mathrm{H} / \mathrm{adw} 4 \mathrm{q}^{+}$ & F93I \\
\hline HBVI7 & Chronic hepatitis & 8480 & 11,15 & $\mathrm{H}$ & $\mathrm{H} / \mathrm{adw} 4 \mathrm{q}^{+}$ & \\
\hline HBVI8 & Chronic hepatitis & 3260 & 11,15 & $\mathrm{H}$ & $\mathrm{H} / \mathrm{adw} 4 \mathrm{q}^{+}$ & $\mathrm{A} 128 \mathrm{~V}$ \\
\hline HBV2I & Chronic hepatitis & 6440000 & $8,9,11,15$ & $\mathrm{C} / \mathrm{H}$ & $\mathrm{Cladrq}^{+}$ & \\
\hline
\end{tabular}


Table 3: Frequency of aminoacid variants in the "a" determinant of HBsAg in strains from asymptomatic and symptomatic Mexican carriers.

\begin{tabular}{|c|c|c|}
\hline amino acid variant & $\%$ in asymptomatic $(n=21)$ & $\%$ in symptomatic $(n=12)$ \\
\hline TIIJS & 79 & 92 \\
\hline SII4T & 84 & 92 \\
\hline $\mathrm{R} / 22 \mathrm{~K}$ & 95 & 100 \\
\hline II $26 \mathrm{~T}$ & 95 & 92 \\
\hline $\mathrm{PI} 27 \mathrm{~V}$ & 5 & 0 \\
\hline PI27L & 79 & 92 \\
\hline $\mathrm{Al} 28 \mathrm{~V}$ & 0 & 8 \\
\hline PI29L & 5 & 0 \\
\hline QI29H & 5 & 0 \\
\hline II50R & 5 & 0 \\
\hline $\mathrm{FI} 58 \mathrm{H}$ & 5 & 0 \\
\hline AI59P & 5 & 0 \\
\hline AI59G & 47 & 92 \\
\hline RI60E & 5 & 0 \\
\hline RI60K & 42 & 83 \\
\hline RI60N & 0 & 8 \\
\hline FI6IS & 5 & 0 \\
\hline FI6IY & 42 & 83 \\
\hline LI62Y & 5 & 0 \\
\hline EI64A & 5 & 0 \\
\hline SI67G & 5 & 0 \\
\hline VI68A & 16 & 42 \\
\hline RI69F & 5 & 0 \\
\hline
\end{tabular}

was identified in four of the 21 asymptomatic cases. Alternatively, LMV treatment in the symptomatic cases might be selecting for the H genotype. Diversity of HBV genotypes may also affect the accuracy of diagnostic tests and therapeutic decisions [32].

HBV has been classified in eight genotypes, A through $\mathrm{H}$ [18], which show a geographic distribution. In this study, genotype $\mathrm{H}$ was found as the predominant genotype in Mexican strains, followed by genotypes $\mathrm{C}$ and F. Genotype $\mathrm{H}$ has a close phylogenetic relationship with genotype $\mathrm{F}[17,18]$. The genotype $\mathrm{C}$ is reported as prevalent in Asian populations $[20,33]$, and patients observed in our population might correspond to imported cases, due to the increased mobility among Asian and Latin-American countries; in fact, recent reports have documented the presence of $\mathrm{HBV}$ genotype $\mathrm{H}$ strains among Japanese blood donors [34], as an evidence of the global mobility. The genotype prevalent in a population may determine the type of mutations prevalent in the infecting strains [35]; for example, the immune-escape mutant G145R is closely associated with genotype D [36]. HBsAg has also been classified in subtypes based on the sequence of the $S$ gene and in identification of the amino acids encoded at specific positions [33]; in our population, subtypes, like genotypes, were more diverse among strains from asymptomatic carriers than in symptomatic cases.
The hepatic function tests and HBV viral load showed that in our symptomatic patients there was hepatic damage and high viral replication, which suggests that the antiviral treatment with LMV was not working, even thought the drug was administered for at least one year in all cases. It is likely that after a long failed therapy, resistance to LMV has been developed. The main mutations associated with LMV resistance are located at the RT gene in the 204 position (rtM204I/V), which is in the catalytic YMDD motif. The $P$ gene overlaps the $S$ gene and thus mutations selected during antiviral treatment may cause concomitant changes to the overlapping reading frame; in particular altering the $\mathrm{C}$-terminal region of HBsAg. Thus for mutations associated with LMV resistance, the rtM204V change is associated with a I195M change in the $S$ gene (sI195M), while the rtM204I change is associated with three possible changes in the $S$ gene, sW196S, sW196L, or a stop codon. In addition, mutation rtA181T is associated with the stop mutation sW172stop in the $S$ gene [37]. However, in our study, none of these mutations were found in the $S$ gene of the strains from symptomatic cases.

There has been several reports on HBV $S$ gene mutants affecting amino acid position 120, 123, 124 126, 129, $131,141,144$ and 145 of the "a" determinant and preS region. The most relevant mutations seem to be the substitutions of amino acid G145R, K141E and T131I and 
insertion of 3 amino acids between residues 123 and 124, since they markedly affect the antigenic structure of HBsAg [38]. Mexican strains of the present study showed mutations at the first and second loop of the "a" determinant; although it should be noted that these mutations differed between asymptomatic and symptomatic strains. Thus, in the asymptomatic cases mutations were found at positions 100, 126, 129, and 146, whereas in symptomatic patients mutation were in positions 93 and128; none of the above mutations are reported to affect significantly the antigenic structure of the protein. It should be emphasized that all cases included in the study were selected because they were HBsAg positive and so those patients with mutations rendering the $S$ protein undetectable with the antibodies tested, were excluded.

\section{Conclusion}

In conclusion, we report the genotypes of HVB prevalent in symptomatic and asymptomatic patients in Mexico and show that there is more genetic diversity and mutations in the "a" determinant of HBV strains infecting asymptomatic carriers than in symptomatic patients. In HBV strains from our population genotype $\mathrm{H}$ and subtype adw $4 \mathrm{q}+$ were predominant. The role of viral genotype and subtype, as well as the ethnicity of the host in the determination of the clinical outcome of HBV infection is still unclear, and studies on genotypes infecting populations should help to clarify this issue.

\section{Methods}

\section{Serum and plasma samples}

Blood samples were drawn from 21 asymptomatic blood donors, at the Central Blood Bank, Centro Médico Nacional-Siglo XXI (CMN-SXXI), Instituto Mexicano del Seguro Social (IMSS), and from 12 symptomatic patients attending the Hepatitis Clinic, Gastroenterology Service, General Hospital, CMN-SXXI-IMSS. All 33 patients were selected because they were known to be HBsAg carriers. Symptomatic cases were receiving lamivudine (LMV) treatment during at least one year. The study was approved by the IRB Committee of IMSS. Informed consent was obtained from all studied participants.

\section{Serology}

Assay for HBsAg was performed in sera using a commercial HBsAg test (version 2 IMx, Abbott Laboratories, IL, USA) following manufacturer's instructions. Hepatic function tests (ALT, AST, Billirubins) were performed using the commercially available Dimension ${ }^{\circledast}$ Clinical Chemistry System (Dade Behring, Inc. Neward, DE, USA).

\section{Viral load}

HBV viral load was determined in plasma with a commercial quantitative assay (COBAS AMPLICOR HBV Moni- tor $^{\mathrm{rm}}$, Roche Diagnostics, Indianapolis, IN, USA) according to manufacturer's instructions.

\section{DNA extraction}

HBV DNA was extracted from plasma specimens with QIAamp ${ }^{\circledR}$ Ultrasens $^{\circledast}$ Virus kit (QIAGEN) following manufacturer's instructions.

\section{PCR amplification of the $S$ gene}

A fragment of the $S$ gene was amplified by nested PCR. Sequences of the primers and their relative positions were as follows: outer primers included HBV1-sense, 5'-CGC TGG ATG TGT CTG CGGCGT-3', position 371-391, and HBV2-antisense, 5'-CGA ACC ACT GAA CAA ATG GCA CT-3', position 682-704; inner primers were HBV3-sense, 5'-CAT CCT GCT GCT ATG CCT CAT CT-3', position 409431 and HBV4-antisense, 5'-GGC ACT AGT AAA CTG AGC CA-3', position 668-687 (30). Ten $\mu \mathrm{L}$ of DNA extracted from plasma (template) were mixed with $40 \mu \mathrm{L}$ of reaction mixture containing $1 \times$ PCR Buffer, 50 pmoles of each primer, $0.8 \mathrm{mM} \mathrm{dNTPs,} 2.5 \mathrm{mM} \mathrm{MgCl}_{2}$, and $2.5 \mathrm{U}$ Taq polymerase (Amplificasa ${ }^{\circledR}$ BIOGÉNICA, Mexico City, Mexico). Annealing and elongation for both primer pairs was for $90 \mathrm{sec}$ at $47^{\circ} \mathrm{C}$ and $72^{\circ} \mathrm{C}$, respectively. The first PCR was carried out for 45 cycles and the nested PCR for 40 cycles, using an initial denaturing step of $95^{\circ} \mathrm{C}$ for 2 min and a final amplification step of $72^{\circ} \mathrm{C}$ for $15 \mathrm{~min}$ [39].

\section{Sequencing}

PCR products ( $279 \mathrm{bp}$ ) were run in $2 \%$ agarose gel electrophoresis and the isolated band was extracted with a commercial kit (QIAquick ${ }^{\circledast}$ Gel Extraction Kit, QIAGEN). The purified product was used for sequencing with the chain termination method, using Big Dye Terminator version 3.1 (ABI PRISM $^{\mathrm{TM}}$, Foster City, CA, USA). Extension products were purified (DyeEx ${ }^{\mathrm{TM}} 2.0$ Kit, QIAGEN) and separated in an automated DNA genetic analyzer (377 ABI PRISM $^{\mathrm{TM}}$ ).

\section{Sequence analysis}

Alignment of sequences was done using the Mega 3.1 program and analyzed manually by visual inspection.

\section{Genotyping}

Genotyping was carried out in DNA extracted from plasma samples, using the INNO-LiPA HBV amplification and genotyping tests (Innogenetics, Ghent Belgium), following manufacturer's instructions.

\section{$\mathrm{NCBI}$ genotyping system}

Genotype was also determined by sequence analysis of the 279 bp fragment from HBV "a" determinant, using the genotyping tool available at the National Library of Medicine's National Center for Biotechnology Information 
(NCBI) [40] using BLAST with a set of reference sequences with known genotypes [41].

\section{Competing interests}

The authors declare that they have no competing interests.

\section{Authors' contributions}

MERT: Designed and supervised most of the molecular studies; analyzed sequences and interpreted results. Participated in the preparation of the manuscript.

HAVS: carried out molecular techniques and participated in the analysis of results.

VJB: carried out immunoassays and interpreted the results.

MDV: responsible for the clinical aspects of the study, including the recruitment of patients; participated in the writing of the manuscript.

JT: Participated in the designed of the study and in the analyses and interpretation of the results. Critical review and edition of the manuscript.

OMH: Participated in the clinical designed of the study and in obtaining financial support for the study.

MTAM: responsible for the design of the study and for acquiring financial support. Supervision of the experimental work. Participated in the drafting of the manuscript.

\section{Acknowledgements}

This work was supported by the Instituto Mexicano del Seguro Social (IMSS), Coordinación de Investigación en Salud (grant FP2003-040). The authors are grateful to Juan Burgueño-Ferreira, Ph.D. for statistical analysis; Othón Rojas-Montes, Mario Valle-Aguirre, Ma.-Carmen Real-Rosas for technical support.

\section{References}

I. Tiollais P, Pourcel C, Dejean A: The hepatitis B virus. Nature 1985 , 3 I 7:489-495.

2. Kennedy RC, lonescu-Matiu I, Alder-Storthz K, Henkel RD, Sánchez Y, Dreesman GR: Characterization of anti-hepatitis B surface antigen monoclonal antibodies. Intervirology 1983, I9: I76-180.

3. Howard CR, Allison LM: Hepatitis $\mathbf{B}$ surface antigen variation and protective immunity. Intervirology 1995, 38:35-40.

4. Rehermann B, Manns MP: Immunologic aspects of acute and chronic hepatitis B and C. Curr Opin Gastroenterol 1996, I 2:554-559.

5. Hong-Yuan H, Mei-Hwei C, Yen-Hsiung L, Shih-Ming W, Ding-Shinn $C$ : Surface gene mutants of Hepatitis $B$ virus in infants who develop acute or chronic infections despite immunoprophylaxis. Hepatology 1997, 26:786-79I.

6. Poovorawan $Y$, Theamboonlers A, Chongsriasawat V, Sanpavat S: Molecular analysis of the a determinant of HBsAg in children of $\mathrm{HBeAg}$-positive mothers upon failure of postexposure prophylaxis. Int J Infect Dis 1998, 2:216-220.

7. Wands JR, Zurawski VR: High affinity monoclonal antibodies to hepatitis B surface antigen(HBsAg) produced by somatic cell hybrids. Gastroenterology I981, 80:225-232.
8. Bhatnagar PK, Papas E, Blum HE, Milich DR, Nitecki D, Kareles MJ, Vyas GN: Immune response to synthetic peptide analogues of Hepatitis $B$ surface antigen specific for the a determinant. Proc Natl Acad Sci USA 1982, 79:4400-4404.

9. Strick HJ, Thornton JM, Howard CR: A topological model for Hepatitis B surface antigen. Intervitology |992, 33:|48-I58.

10. Carman WF, Van Deursen FJ, Mimms LT, Hardie D, Coppola R, Decker R, Sanders R: The prevalence of surface antigen variants of Hepatitis B virus in Papua, New Guinea, South Africa and Sardinia. Hepatology 1997, 26: I658-I666.

II. Cooreman MP, Van-Rossmalen MH, Te Morsche R, Sünnen CMG, Schoondermark-van de Ven EME, Jansen JBM, Tytgat GNJ, de Witt PM, Paulij VP: Characterization of the reactivity pattern of murine monoclonal antibodies against wild type hepatitis $B$ surface antigen to G I45R and other naturally occurring " $a$ " loop escape mutations. Hepatology I999, 30: I 287-I 292.

12. Chen WN, Oon CHJ, Toh I: Altered antigenicities of hepatitis B virus surface antigen carrying mutations outside the common "a" determinant. Am J Gastroenterol 2000, 95: 1098-1099.

13. Brown JL, Carman WF, Thomas HC: The clinical significance of molecular variation within the hepatitis $B$ virus genome. Hepatology 1992, I5: |44-148.

14. Asahina Y, Enomoto N, Ogura Y, Kurosaki M, Sakuma I, Izumi N, Marumo F, Sato C: Sequential changes in full-length genomes of hepatitis $B$ virus accompanying acute exacerbation of chronic hepatitis B. J Hepatol 1996, 25:787-794.

15. Weinberger KM, Bauer T, Böhm S, Jilg W: High genetic variability of the group-specific a-determinant of hepatitis $B$ virus surface antigen (HBsAg) and the corresponding fragment of the viral polymerase in chronic virus carriers lacking detectable HBsAg in serum. J Gen Virol 2000, 81: I I65-I I74.

16. Norder H, Couroucé AM, Magnius LO: Complete genomes, phylogenetic relatedness and structural proteins of six strains of the hepatitis B virus, four of which represent two new genotypes. Virology 1994, 198:489-503.

17. Stuyver L, De Gendt S, Van Geyt C, Zoulim F, Fried M, Schinazi RF, Rossau R: A new genotype of hepatitis $B$ virus: complete genome and phylogenetic relatedness. J Gen Virol 2000, $81: 67-74$.

18. Arauz-Ruiz P, Norder H, Robertson BH, Magnius O: Genotype $\mathbf{H}$ : a new Amerindian genotype of hepatitis $B$ virus revealed in Central America. J Gen Virol 2002, 83:2059-2073.

19. Norder H, Hammas B, Löfdahls S, Couroucé AM, Magnius LO: Comparison of the aminoacid sequences of nine different serotypes of Hepatitis B surface antigen and genomic classification of the corresponding hepatitis B virus strains. J Gen Virol 1992, 73: I201-1208.

20. Norder H, Hammas B, Lee SD, Bile K, Couroucé AM, Mushahwar IK Magnius LO: Genetic relatedness of Hepatitis B viral strains of diverse geographical origin and natural variations in the primary structure of the surface antigen. J Gen Virol 1993, 74: $134 \mid-1348$.

21. Okamoto H, Tsuda F, Sakugawa H, Sastrosoewignjo RI, Imai M, Miyakawa $Y$, Mayumi M: Typing hepatitis B virus by homology in nucleotide sequence: comparison of surface antigen subtypes. J Gen Virol 1988, 69:2575-2583.

22. Arauz-Ruiz P, Norder H, Visoná KA, Magnius LO: Genotype F prevails in $\mathrm{HBV}$ infected patients of hispanic origin in Central America and may carry the precore stop mutant. J Med Virol |997, 5 I:305-3 |2.

23. Arauz-Ruiz P, Norder H, Visoná KA, Magnius LO: Molecular epidemiology of hepatitis $B$ virus in Central America reflected in the genetic variability of the small $\mathbf{S}$ gene. J Infect Dis 1997, I 76:851-858.

24. Bowyer SM, van-Staden L, Kew MC, Sim JGM: A unique segment of the hepatitis B virus group A genotype identified in isolates from South Africa. J Gen Virol 1997, 78: I719-1729.

25. Telenta PF, Palacios Poggio G, López JL, González J, Lemberg A, Campos RH: Increased prevalence of genotype $\mathbf{F}$ hepatitis B virus isolates in Buenos Aires, Argentina. J Clin Microbio 1997, 35:1873-1875.

26. Sablon E, Shapiro F: Advances in molecular diagnosis of HBV infection and drug resistance. Int J Med Sci 2005, 2:8- 16.

27. Alvarez-Muñoz MT, Bustamante-Calvillo ME, Guiscafré-Gallardo JP, Muñoz O: Hepatitis B and delta: the prevalence of seroepide- 
miological markers in volunteer blood donors and their families. Gac Med Mex 199I, 1 27:399-404.

28. Tanaka J: Hepatitis B epidemiology in Latin America. Vaccine 2000, I 8:SI7-SI9.

29. Vivas-Arceo C, Bastidas-Ramírez BE, Panduro A: Hepatocellular carcinoma is rarely present in Western Mexico. Hepatol Res 1999, 16:26-35.

30. Sánchez LV, Maldonado M, Bastidas-Ramírez BE, Norder H, Panduro A: Genotype and S-gene variability of Mexican hepatitis B virus strains. J Med Virol 2002, 68:24-32.

31. Kao JH, Chen PJ, Lai MY, Chen DS: Hepatitis B genotypes correlate with clinical outcome in patients with chronic hepatitis B. Gastroenterology 2000, I I 8:554-59.

32. Bartholomeusz A, Schaefer S: Hepatitis B virus genotypes:comparison of genotyping methods. Rev Med Virol 2004, 14:3-16.

33. Echevarría JM, Avellón A: Hepatitis B virus genetic diversity. 2006, 78:S36-S42.

34. Ohnuma H, Yoshikawa A, Mizoguchi H, Okamoto H: JRC NAT Screening Research Group. Characterization of genotype $\mathbf{H}$ hepatitis $B$ virus identified for the first time from a Japanese blood by nucleic acid amplification test. J Gen Virol 2005, 86:595-599.

35. Campos RH, Mbayed VA, Pineiro Y, Leone FG: Molecular epidemiology of hepatitis B in Latin America. J Clin Virol 2005, 34:S8-SI3.

36. Carman WF: The clinical significance of surface antigen variants of hepatitis B virus. J Viral Hepatitis 1997, 4: II-20.

37. Bartholomeusz A, Locarnini $S$ : Hepatitis $B$ virus mutations associated with antiviral therapy. J Med Virol 2006, 78:S52-S55.

38. Seddigh-Tonekaboni S, Waters JA, Jeffers S, Gehrke R, Ofenloch B, Horsch A, Hess G, Thomas HC, Karayiannis P: Effect of variation in the common " $\mathrm{a}$ " determinant on the antigenicity of hepatitis B surface antigen. J Med Virol 2000, 60:1I3-2I.

39. Nainan OV, Khristova ML, Byun KS, Xia G, Taylor PE, Stevens CE, Margolis HS: Genetic variation of hepatitis B surface antigen coding region among infants with chronic hepatitis $B$ virus infection. J Med Virol 2002, 68:319-327.

40. Genotyping Tool [http://www.ncbi.gov/projects/genotyping/form page.cgi]

41. Rozanov M, Plikat U, Chappey C, Kochergin A, Tatusova T: A webbased genotyping resource for viral sequences. Nucleic Acids Res 2004, 32:W664-W659.
Publish with Bio Med Central and every scientist can read your work free of charge

"BioMed Central will be the most significant development for disseminating the results of biomedical research in our lifetime. "

Sir Paul Nurse, Cancer Research UK

Your research papers will be:

- available free of charge to the entire biomedical community

- peer reviewed and published immediately upon acceptance

- cited in PubMed and archived on PubMed Central

- yours - you keep the copyright 